\title{
Quantitative and qualitative analysis of sugarcane productivity in function of air temperature and water stress
}

\author{
Derblai Casaroli*, José Alves Júnior, Adão Wagner Pêgo Evangelista
}

Federal University of Goias, Goiânia, Brazil

*Corresponding author, e-mail: derblai@ufg.br

\begin{abstract}
Climate variables can influence the both productivity and quality of the commercial product of sugarcane crop. This study aimed to evaluate the influence of thermal time, negative degreedays and water deficit on productivity and industrial quality of sugarcane for the Goiás Brazilian Savanna region. The data of productivity and industrial quality were obtained in the field (Plant Centro Álcoo( $\left.{ }^{\circledR}\right)$ and climate data in the weather station. Thermal time and the accumulation of negative degree-days in cycles showed significant correlations with the yield. The highest $(340 \mathrm{~mm})$ and the lowest $(158 \mathrm{~mm})$ accumulated water deficit blade not reflected in lower productivity and greater, respectively. Relative evapotranspiration (rET) was equal at 1.0 in more than $50 \%$ of the studied period, in which not were found significant correlations between the $r E T<1$ with the productivity and industrial quality. We found significant correlations between rates of degree-days and negative degree-days with productivity rates; however, there was a low correlation between the water deficit rates and productivity. The total recoverable sugars rates and total soluble solids showed maximum accumulation point only in function of degree-day rates. We conclude that the thermal time has greater influence on yield decrease of sugarcane with different harvest cycles, significantly contributing to the accumulation of sugars in the stem.
\end{abstract}

Keywords: Saccharum spp., climatological characteristics, soil water content, yields decrease

\section{Introduction}

Sugarcane (Saccharum spp.) is one of the main crops in tropical areas around the world. This crop is important mainly due to the production of sugar and alcohol. However, it has currently shown a great energy production capacity due to the burning of its dry matter (Silva et al., 2007; Trentin et al., 2011).

The production system of sugarcane and other crops can be affected by factors related to the plant, soil, cultural practices and climate conditions (Marin et al., 2013).

In Brazil, because of its large territorial extensions, sugarcane has been grown under many different environmental conditions. Both the soil and the climate of the region influence the production and quality of sugarcane (Loarie et al., 2011 ; Oliveira et al., 2012; Marin \& Carvalho, 2012; Marin et al., 2013; Zhao \& Li, 2015). Models estimating productivity based on climate variables allows monitoring their effects throughout the crop cycle, which allows quantifying potential yield decrease due to restrictions imposed on the crop (Oliveira et al., 2012).

Air temperature and soil water content are variables that affect quantitatively and qualitatively growth, development, maturation and consequently productivity of sugarcane (Scarpari \& Beauclair, 2009; Marin \& Carvalho, 2012). When temperature exceeds $20^{\circ} \mathrm{C}$, there 
is an increase in the growth rate of sugarcane crops, with an optimal range of $25-33^{\circ} \mathrm{C}$ for its growth and development. Yet, for some regions of Brazil, $18-20^{\circ} \mathrm{C}$ temperatures are considered critical to crop growth (Almeida et al., 2008). In addition, regions with severe water deficit $(>120$ $\mathrm{mm}$ ) may experience significant yield decrease (Araujo et al., 2016; Campos et al., 2014). On the other hand, water deficit periods are responsible for the initial stimulus in changing the development stage of the plant, leading it to the maturity stage. It also favors the accumulation of sugars in the culm (Caputo et al., 2007; Machado et al., 2009).

Brazilian Savanna region has been considered as the new agricultural frontier for sugarcane, especially Goiás State, the second largest sugar producer in Brazil (Conab, 2016). However, the average productivity of the region is still lower than that obtained in São Paulo, the largest producer. This is mainly due to the lack of specific technical and scientific information focused on the region, which has edaphoclimatic characteristics different from traditional growing regions in the country.

The aim of this study was to evaluate the influence of the thermal time, negative degreedays and water stress on the productivity and industrial quality of sugarcane for the Goiás Brazilian Savanna region.

\section{Materials and Methods}

The experiment was conducted in an experimental unit of the Centro Álcoo ${ }^{\circledR}$ sugar plant located in Santo Antônio de Goiás, GO, Brazil. According to the Köppen Climate Classification, the climate is Aw (tropical with dry season). The planting was performed on May 1, 2008 and the plant-cane cultivation (18 months) was evaluated. The first cut was made on November 15, 2009. It was followed by the ratoon crops ( $\approx 12$ months), with cuts made on September 17, 2010 (2 $\left.2^{\text {nd }} c u t\right)$, September 30, 2011 (3rd cut), and August 20, 2012 (4 $4^{\text {th }}$ cut). Meteorological data such as wind speed, temperature, relative humidity, solar radiation and rainfall were collected at the Embrapa Meteorological Station Rice and Beans, located in Santo Antônio de Goiás, GO, approximately 6 $\mathrm{km}$ from the experimental area.

The sugarcane variety RB-86-7515 was cultivated. It has the following characteristics: non-demanding on soil fertility, late maturation, good yield transport, good mechanical harvesting, good ratoon budding, excellent ratoon budding with straw, regular inter-row closing, rare flowerings, excellent response to maturation and tolerance to drought (RIDESA, 2008). Three experimental plots were demarcated within the sugar plant growing area: $15 \mathrm{~m}$ long and 5 cultivation lines (spaced $1.5 \mathrm{~m}$ ). It was a completely randomized design considering the homogeneity of the area. Treatments were different cuts over time. The productivity was evaluated in terms of quantity in tons of sugarcane culms per hectare (TSH), and industrial quality was expressed as total recoverable sugars (TRS, $\mathrm{kg} \mathrm{t}^{-1}$ ) and total soluble solids ('Brix, \%) depending on the different cuts (plant-cane, ratoon 1, ratoon 2, ratoon 3). The thermal time during the cultivation of sugarcane was also evaluated. It was determined from the sum of degrees days ( $T+=\Sigma D D$ ) accumulated in the period. It was calculated according to the methodology proposed by Villa Nova (1972) using $20^{\circ} \mathrm{C}$ as low basal temperature of sugarcane crops for upland rice crops (Bacchi \& Souza, 1977). The calculation of negative degree-days (NDD) followed the methodology proposed by Scarpari (2009).

A daily sequential water balance, according to Thornthwaite and Mather, was applied with an available water capacity (AWC) equal to $106.76 \mathrm{~mm}$ obtained from the effective depth of the average sugarcane root system $(0.68 \mathrm{~m})$, from water content at field capacity $\left(\theta_{\mathrm{FC}}=0.405 \mathrm{~m}^{3} \mathrm{~m}^{-3}\right)$ and permanent wilting point $\left(\theta_{\text {pwp }}=0.248 \mathrm{~m}^{3} \mathrm{~m}^{-3}\right)$. From ETc $\left(\mathrm{mm} \mathrm{day}^{-1}\right)$ and ETR $\left(\mathrm{mm}\right.$ day $\left.^{-1}\right)$ values from water balance, relative evapotranspiration values ( $\mathrm{EET}=\mathrm{ETR} / \mathrm{ETC}$ ) were obtained.

The FAO-33 Model was used to estimate the maximum yield or potential productivity (PP) and water depletion (water stress) for sugarcane (Doorenbos \& Kassam, 1979).

The field permanence times of plants were different for plant-cane (564 days), ratoon 1 (305 days), ratoon 2 (379 days) and ratoon 3 
(324 days). Thus, aiming to eliminate the effect of time, the determination of rates of variables obtained in plants (TSH, TRS, ${ }^{\circ}$ Brix) and climate (DD, NDD and DEF) was made.

Productivity data were subjected to analysis of variance and means were compared by Tukey test $(p<0.05)$. Data were correlated to climatic variables.

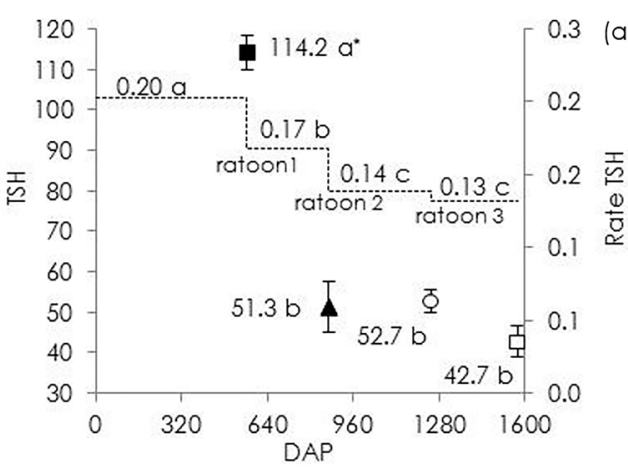

\section{Results and Discussion}

Quantitative productivities showed significant differences depending on cuts only between plant-cane and ratoon-cane cycles. The plant-cane cycle had the highest average: 114 t ha-1 $^{-1}$ (Figure 1).

Productivity varies in function of the edaphoclimatic potential of the region,

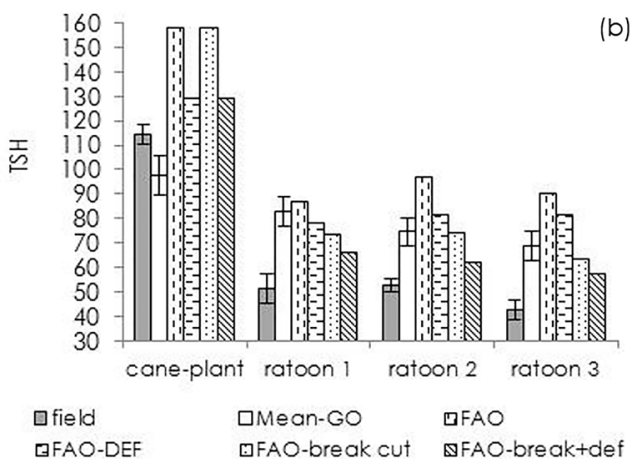

Figure 1. (a) Ton of sugarcane steam per hectare (TSH, $\dagger$ ha $\left.^{-1} \mathrm{cycle}^{-1}\right)$ and their rates ( $\mathrm{h} \mathrm{ha}^{-1} \mathrm{day}^{-1}$ ) in function of cycle: plant-cane (-), ratoon 1 ( $\mathbf{\Lambda}$ ), ratoon 2 (०) e ratoon 3 (). (b) TSH obtained in experiment (field), mean to Goiás (Mean-GO), to FAO model (FAO) and FAO in function of water stress (FAO-DEF). Yield decrease per cycle (Yd\%) to experimental area and to state of Goiás.

averaging $85 \mathrm{tha}^{-1}$ in the first five cuts. It may reach up to 110 tha-1 $^{-1}$ in places with a high technology implemented (Machado et al., 2009).

Evaluation of productivity rates showed significant differences among the cuts. The highest averages were detected in the plantcane cycle followed by the other cuts (Figure 1). Ratoon cycles showed reductions of $17.3 \%, 31.2 \%$ and $35.1 \%$ in their TSH accumulation rates day ${ }^{-1}$ respectively for ratoon 1 , ratoon 2 and ratoon 3 in relation to the accumulation recorded for the plant-cane.

Physiologically, it is known that the productivity of the ratoon tends to gradually decrease with the increase of the cut stages. This may occur because the roots of ratoon are shallower than plant-cane roots (Baquero et al., 2012), being the root system (rhizomes and roots) essential for the regrowth of ratoon, for it is a stock of energy and nutrition (Trentin et al., 2011). This can be evidenced by the productivity data of cuts for the state of Goiás published by CONAB regarding 2007/08 to 2011/12 crops (http://www. conab.gov.br), which show yield decrease from the second cut for all crop-years (Figure 1).

The average productivity for the state of
Goiás was higher than the average productivity of the experiment within each cycle, except for the plant-cane cycle, in which the values observed in the experiment were higher (Figure 1). Potential productivity estimates generated by the FAO-33 Model were numerically higher when compared to this experiment, but followed the same decrease tendency at every cut. This is because the FAO model takes into consideration the climatic variables involved in plant growth and development and consequently in production (solar radiation and air temperature). Thus, the greater the time of exposure to these variables, the higher the accumulation of plant biomass, hence the difference between different productivities among cycles (field permanence time), which may also have influenced productivities obtained in the experimental field.

The average productivity break values in ratoon cycles obtained in the experimental area were around $57 \%$ compared to the plant-cane cycle. However, the average values for the state of Goiás showed lower breaks, with an average of $23 \%$ (Figure 1). Yield decrease due to cuts in each cycle, obtained for the state of Goiás, were added to the FAO model. Breaks were summed 
to cut and water stress (Figure 1). Thus, the values obtained in the models approached the average values of the state of Goiás and the experimental data, following the same tendency, but with overestimations (Figure 2).

It was found that the ratoon 1 had the highest average of total recoverable sugars

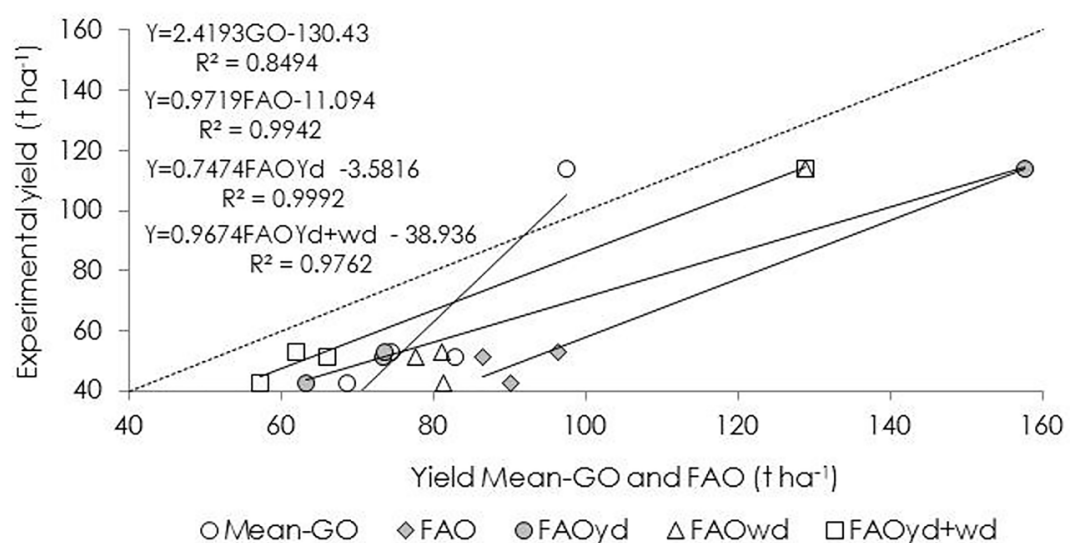

OMean-GO $\diamond F A O$ OFAOyd $\triangle F A O W d$ GFAOyd+wd
Figure 2. Experimental yield $(Y)$ in function of mean to Goias state (Mean-GO), FAO model (FAO), and FAO with yield decrease due to cycle cuts (FAOyd), water stress (FAOwd) and yield decrease plus water stress (FAOyd+wd).

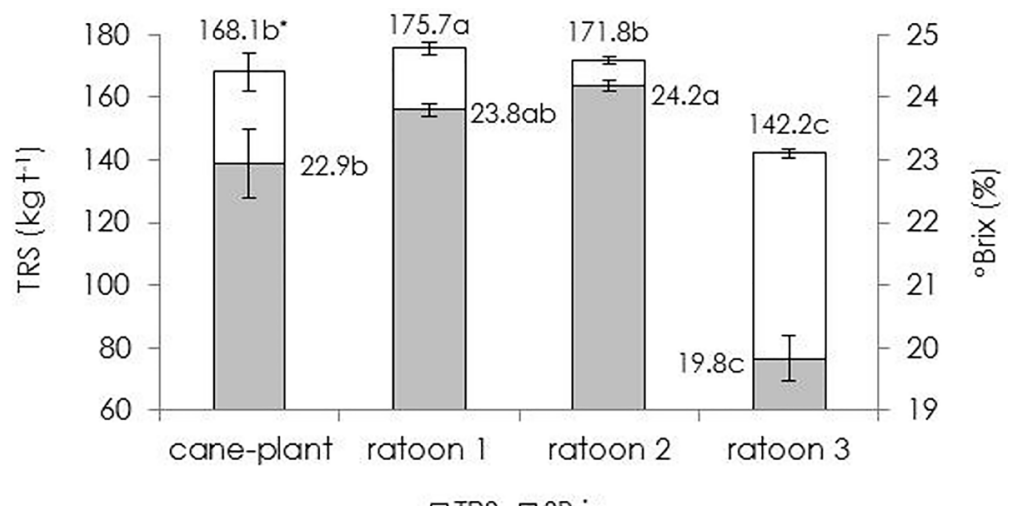

\section{$\square$ TRS $\square$ ०Brix}

"Mean following by same letter in the symbols (CV\%=6.54) and in the dotted line $(C V \%=7.81)$ do not have significant difference by Tukey test at $5 \%$.

Figure 3. Total recoverable sugar content (TRS, $\mathrm{kg} \mathrm{t}^{-1}$ ) and percentage of soluble solids in juice ( ${ }^{\circ}$ Brix, \%) in function of sugarcane cycle cuts: plant-cane, ratoon 1, ratoon 2 and ratoon 3.

(TRS) and the second highest average was total soluble solids ('Brix), which showed no significant difference from ratoon 2 (Figure 3).

TRS and ${ }^{\circ}$ Brix values showed significant correlations $(p<0.05)$ with the total water stress of each cycle ( $r=0.72$ and $r=0.61$, respectively). However, when correlated with thermal time and negative degrees days accumulated in each cycle, the values of $r$ were only significant at $p<0.10(r<0.3)$.

In addition to decreases in productivity due to cutting, this abrupt break of the ratoon cycles, in relation to the plant-cane cycle, may have been influenced by a lower thermal time (Scarpari \& Beauclair, 2009) and/or a sharp water stress (Inman-Bamber \& Smith, 2005; Dantas Neto et al., 2006; Iskandar et al., 2011), as evidenced by the FAO model with deficit. However, in qualitative terms, ratoon 1 had TRS and ratton 2 had ${ }^{\circ}$ Brix averages significantly higher than the plant-cane (Figure 3).

Different thermal times were observed for each sugarcane cycle, as well as different degrees-days accumulation rates (Figure 4). The highest thermal times and degrees days accumulation rates were recorded for the plantcane cycle, and the lowest were observed in the ratoon 3 (Figure 4). These thermal time values and their rates accompanied the sugarcane productivity values (Figure 1).

Ratoon 1 accumulated $50.1 \%$ less degrees days (DD) in relation to the plantcane, and ratoons 2 and 3 accumulated $38.4 \%$ and $55.3 \%$ less DD, respectively. Similar 
percentages were found for yield decrease (Figure 1). Accumulated values of thermal time and negative degrees days showed significant correlations with the productivity $(r=0.98$ and $r=0.99$, respectively) obtained in the experiment, though their rates had lower correlation values $(r=0.85$ and $r=0.71$, respectively). The highest thermal time accumulation rates were recorded in the plant-cane cycle (Figure 4).

A reduction of $8.1 \%, 8.6 \%$ and $22.5 \%$ was observed in the rates of ratoon 1, ratoon 2 and

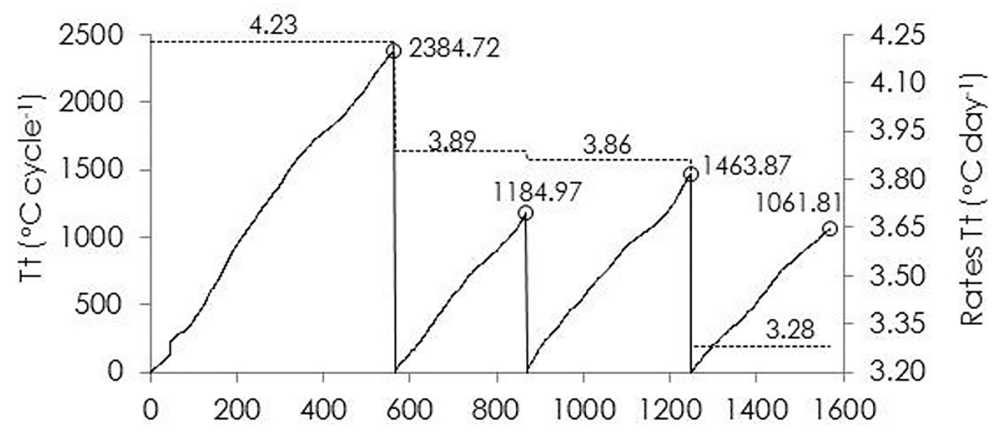

Days after plantation

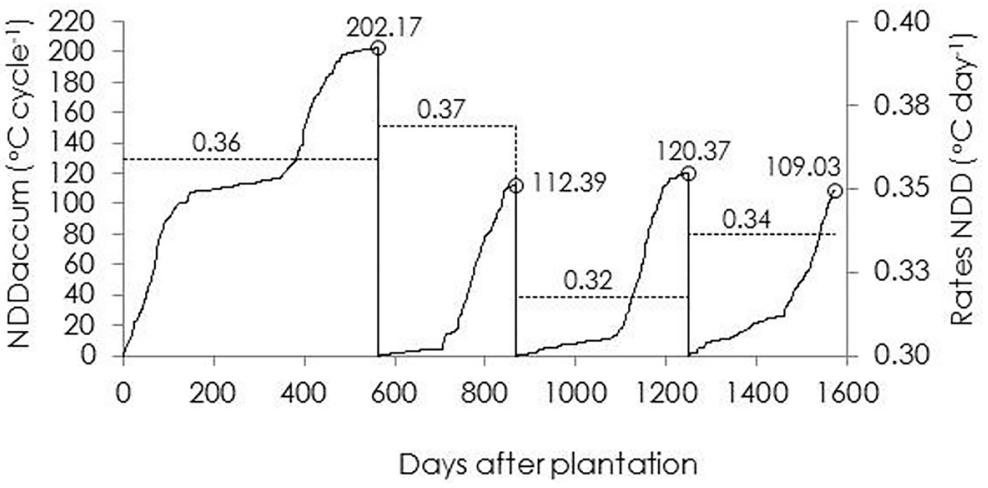

Figure 4. Thermal time per cycle $\left(\mathrm{Tt}^{\circ}{ }^{\circ} \mathrm{C}\right.$ cycle $\left.{ }^{-1}\right)$ and the accumulated negative degree-days per cycle (NDDaccum cycle ${ }^{-1}$ ), as well as their rates Tt day $^{-1}$ and NDDaccum day ${ }^{-1}$.

ratoon 3 cycles, respectively, compared to plantcane (Figure 4). Also in Figure 2, numerically, it was observed that the highest accumulation of negative degrees days occurred in plant-cane, followed by ratoon 2, ratoon 1 and ratoon 3, with an average reduction in their rates in relation to plant-cane equal to $43.6 \%$. It is known that in a given moment of the cycle, an abrupt change in temperature must occur so that maturation occurs, with decreases between 10 and $18^{\circ} \mathrm{C}$ (Marin \& Carvalho, 2012). There was temperature amplitude of $6.3-16.7{ }^{\circ} \mathrm{C}$, with the highest temperatures detected in August and the lowest at the end of January.

The weekly sequential water balance for the sugarcane crop in the four cycles studied in the experiment presented periods of water stress and surplus (Figure 5), which are characteristic of this region. For the plant-cane cycle, the accumulated deficit was $432.1 \mathrm{~mm}$, subdivided into two phases, one in 2008 (271.89 mm) and another in 2009 (160.20 mm). They are numerically similar to the other cycles. When deficit rate values were considered, the highest rate was determined in ratoon 1 cycle $(1.112 \mathrm{~mm}$ day $\left.^{-1}\right)$, followed by plant-cane $\left(0.767 \mathrm{~mm}\right.$ day $\left.^{-1}\right)$, ratoon 2 (0.692 $\mathrm{mm} \mathrm{day}^{-1}$ ) and ratoon 3 (0.486 $\mathrm{mm}$ day $\left.^{-1}\right)$. With this, even accumulating lower daily deficit rates, ratoon $2(36.6 \%)$ and ratoon 3 (31.0\%), compared to plant cane, did not reflect a higher productivity.

Analyzing productivity as a function of real evapotranspiration (ETR, $\mathrm{mm}$ ), a mass gain equal to $9.11,7.74,6.73$ and $10.51 \mathrm{~g} \mathrm{~mm}^{-1}$ was observed, respectively, for plant-cane, ratoon 1 ratoon 2 and ratoon 3 cycles. Considering 100\% of the potential crop evapotranspiration (ETC, $\mathrm{mm})$, productivity increases would be equal 


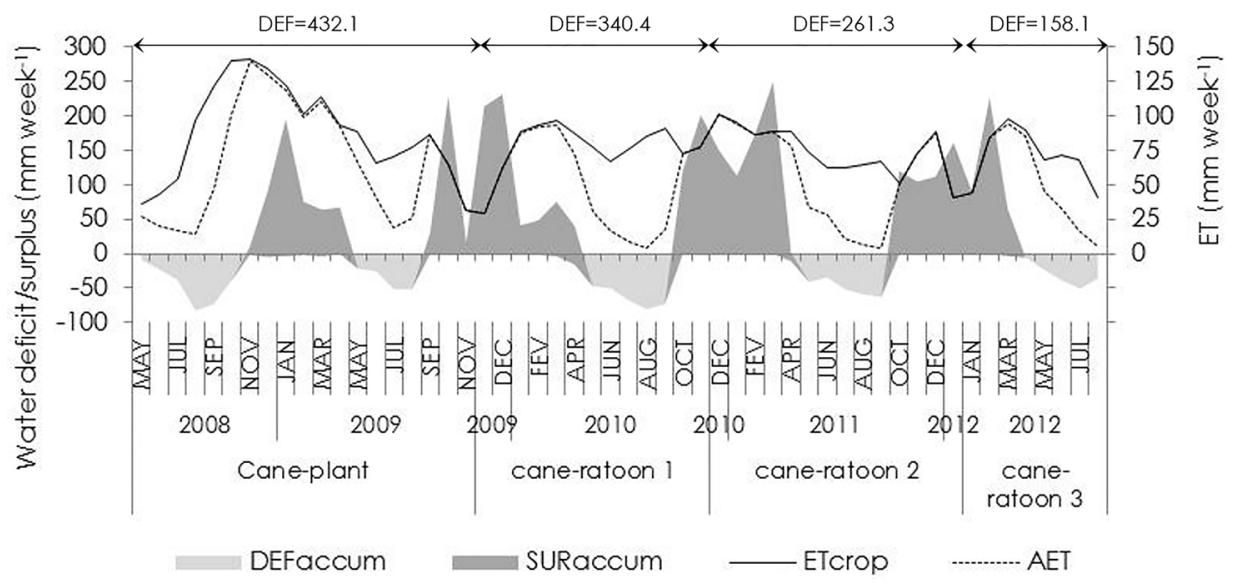

Figure 5. Seven-day water balance (deficit: DEFaccum; surplus: SURacum) to four sugarcane crop cycles, and the crop evapotranspiration (ETcrop) and actual evapotranspiration (AET).

to $39.34,26.33,17.61$ and $16.62+\mathrm{ha}^{-1}$ for plantcane, ratoon 1, ratoon 2 and ratoon 3 cycles, respectively.

The regression equations that better adjusted relative evapotranspiration (ETr) data in function of deficit blades (DEF) and soil water content $(\theta)$ were linear and exponential, both with a $R^{2}>0.80$ (Figure 6). The real behavior of

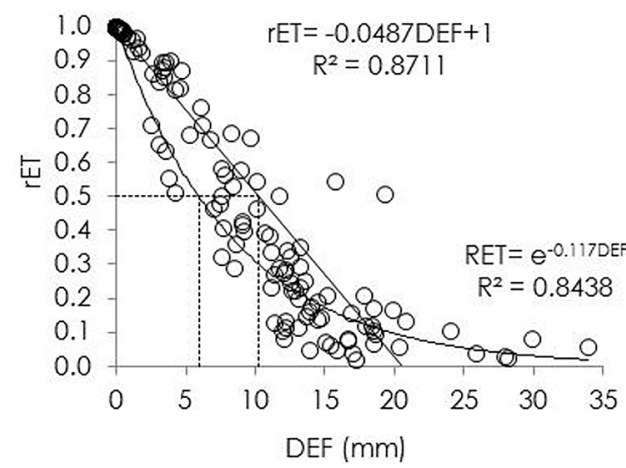

sugarcane plants would be possible only under controlled soil moisture conditions, for example in lysimeter studies. In the literature, there are theoretical behaviors for both linear and exponential adjustments (Casaroli et al., 2010; Metselaar \& Jong Van Lier, 2007).

From the linear adjustment it can be inferred that deficit blades were lower than

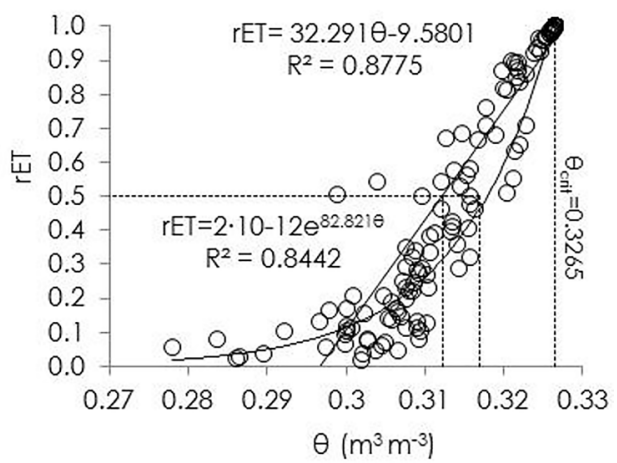

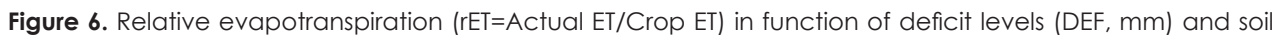
water content $\left(\theta, \mathrm{m}^{3} \mathrm{~m}^{-3}\right)$.

$20.28 \mathrm{~mm}$ and water contents were lower than $0.2967 \mathrm{~m}^{3} \mathrm{~m}^{-3}, \mathrm{rET}=0$. To maintain at least $50 \% \mathrm{ETC}$, there is the need for a water stress blade equal to $10.2 \mathrm{~mm}$ (linear) and $6.0 \mathrm{~mm}$ (exponential) corresponding to water contents of $0.3169 \mathrm{~m}^{3}$ $\mathrm{m}^{-3}$ and $0.3121 \mathrm{~m}^{3} \mathrm{~m}^{-3}$, respectively, for linear and exponential adjustments (Figure 6).

The tillering stages, together with the phase of greatest vegetative growth stage, also known as formation phase, have been identified as a critical period for water demand (Machado et al., 2009). In this study, there were frequency distributions for different rET class ranges for the different sugarcane cycles. For the plant-cane cycle, it was determined that in over $42 \%$ of the cycle relative evapotranspiration ( $\mathrm{rET}$ ) was less than or equal to 0.80 , and in $58 \%$ of the cycle it was greater than 0.80. Furthermore, it was observed that in more than $56 \%$ Of the vegetative growth phase time the rET was $>0.80$. On the other hand, in the formation phase, in $66 \%$ of the time the rET was $\leq 0.40$. For ratoon cycles, there were also rET> 0.80 for most of the time, and this class appeared in $100 \%$ of the time in the formation phase.

Correlating productivity rates (TSH) with thermal time rates and negative degrees days with water stress, coefficients of determination $\mathrm{R}^{2}>0.72$ were observed for rates of accumulated 
degrees days, with a correlation of $r=0.84$ (Figure 7).

Although a significant correlation was observed for negative degrees days, the $\mathrm{R}^{2}$ was only 0.5 . With regard to water stress, a quadratic fit was determined with a high data dispersion and a low correlation $(r=0.48)$. The results of TRS and ${ }^{\circ}$ Brix were also correlated to thermal time, negative degrees days and water stress data, where, again, the values expressed in rates were used (Figure 8).

The relations among TRS, ${ }^{\circ}$ Brix and thermal time showed good fits for the quadratic equation $\left(R^{2}>0.8\right)$, resulting in parables with maximum points around 3.65 DD day ${ }^{-1}$ (Figures $8 \mathrm{a}$ and $8 \mathrm{~d})$. The correlation coefficients were low $(r<0.4)$ and significant only at $p<0.10$ (Figures $8 a$ and $8 d$ ).

The relations with NDD were low $\left(R^{2}<0.4\right)$ and the correlations were not significant (Figure $8 \mathrm{~b}$ and $8 \mathrm{e})$. On the other hand, the correlations with DEF had $R^{2}>0.6$ and significant positive correlations, adjusting second-degree equations whose parabolas had points with a minimum accumulation of TRS and 'Brix at approximately $0.73 \mathrm{~mm} \mathrm{day}^{-1}$ (Figures $8 \mathrm{c}$ and $8 \mathrm{f}$ ). Thus, it can be inferred that for the accumulation of TRS and 'Brix, a maximum accumulation point of thermal time was reached. However, accumulated NDD and DEF values did not reached their potential values.

\section{Conclusions}

The thermal time had the highest degree (a)

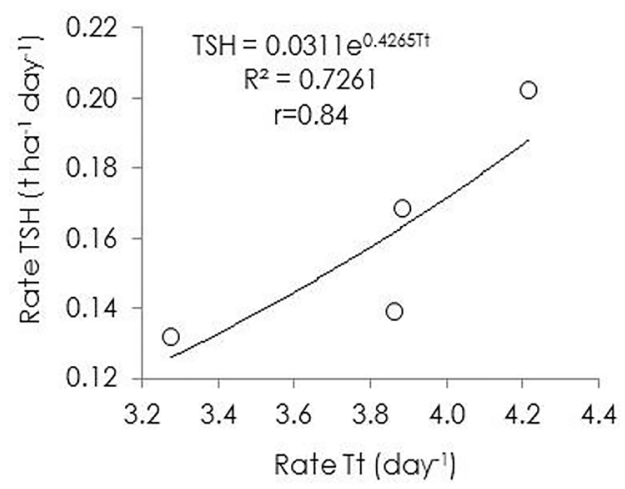

(b)

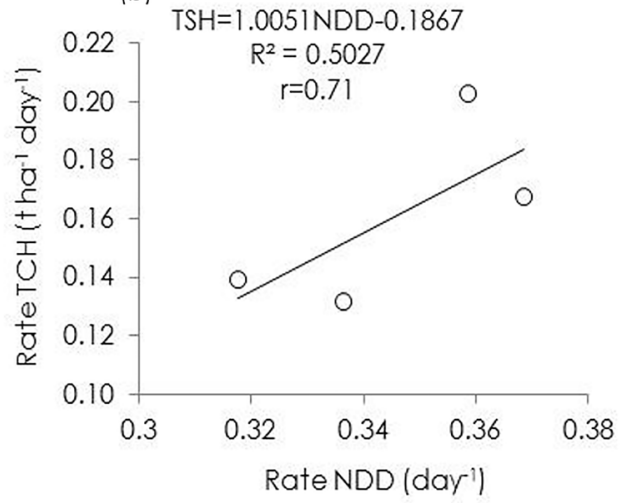

(c) $\mathrm{TSH}=-0,321 \mathrm{DEF}^{2}+0,583 \mathrm{DEF}-0,081$

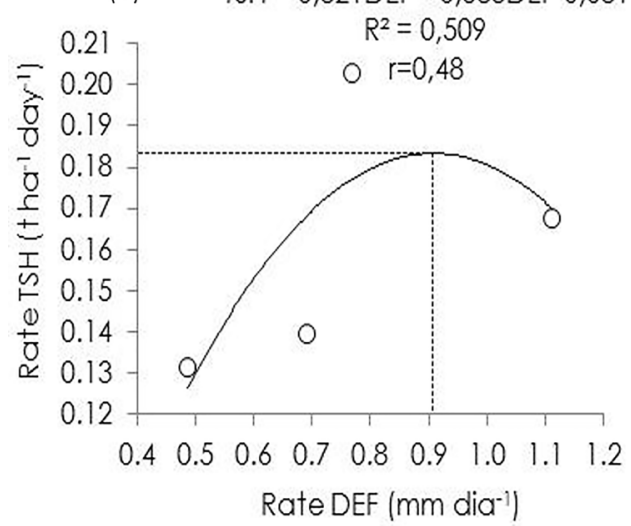

Figure 7. Rate of sugarcane yield in ton of sugarcane per hectare (Rate TSH, $t$ ha $^{-1}$ day $^{-1}$ ), in function of rate thermal time (Rate $\mathrm{Tt}^{\prime}, \mathrm{day}^{-1}$ ), rate negative degree-day (Rate NDD, dia-1) and water stress (Rate DEF, mm $\left.\mathrm{day}^{-1}\right)$. 
(a)

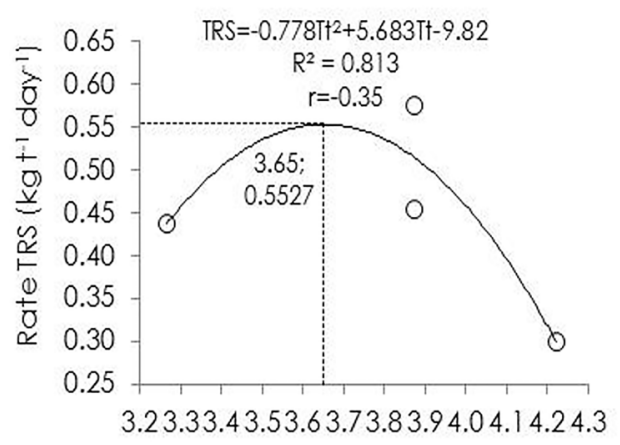

Rate $\left.\mathrm{T \dagger}\left(\mathrm{C}^{\circ} \mathrm{day}\right)^{\prime}\right)$

(c)

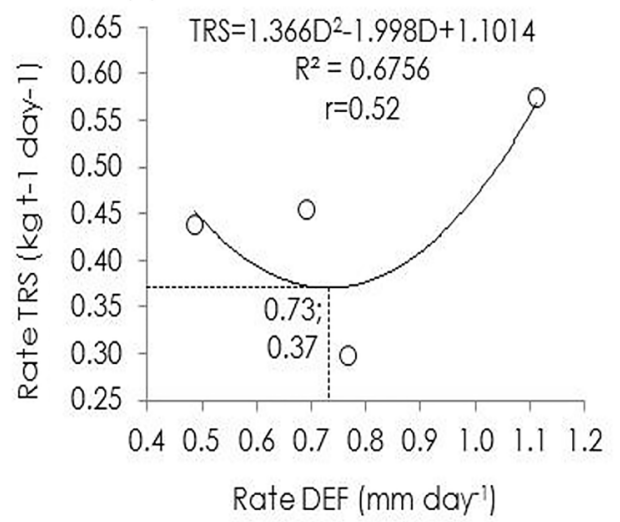

(e)

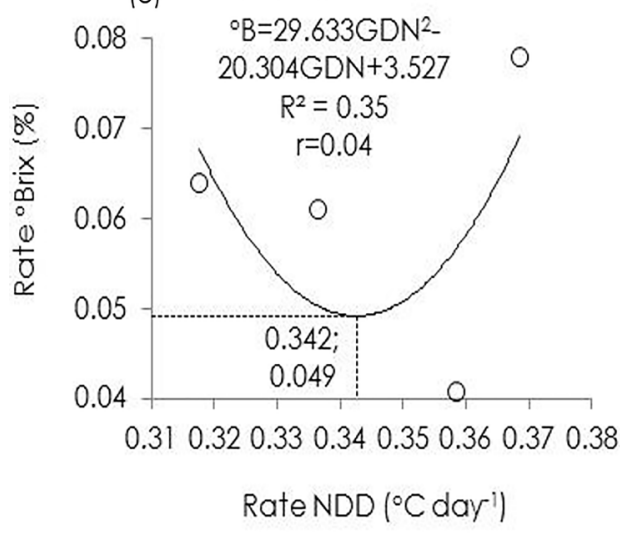

(b)

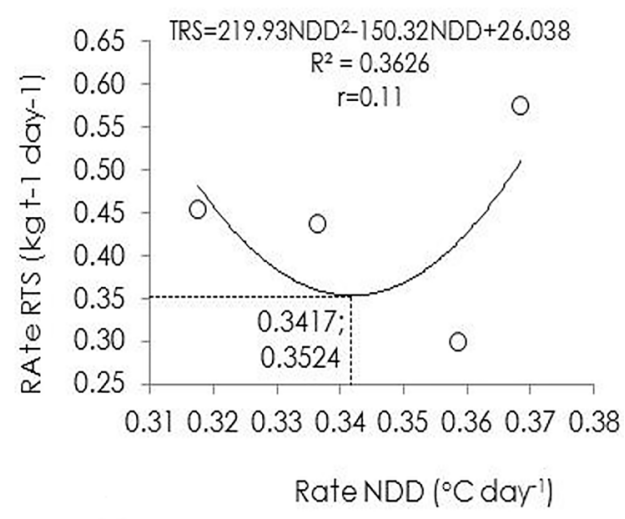

(d)
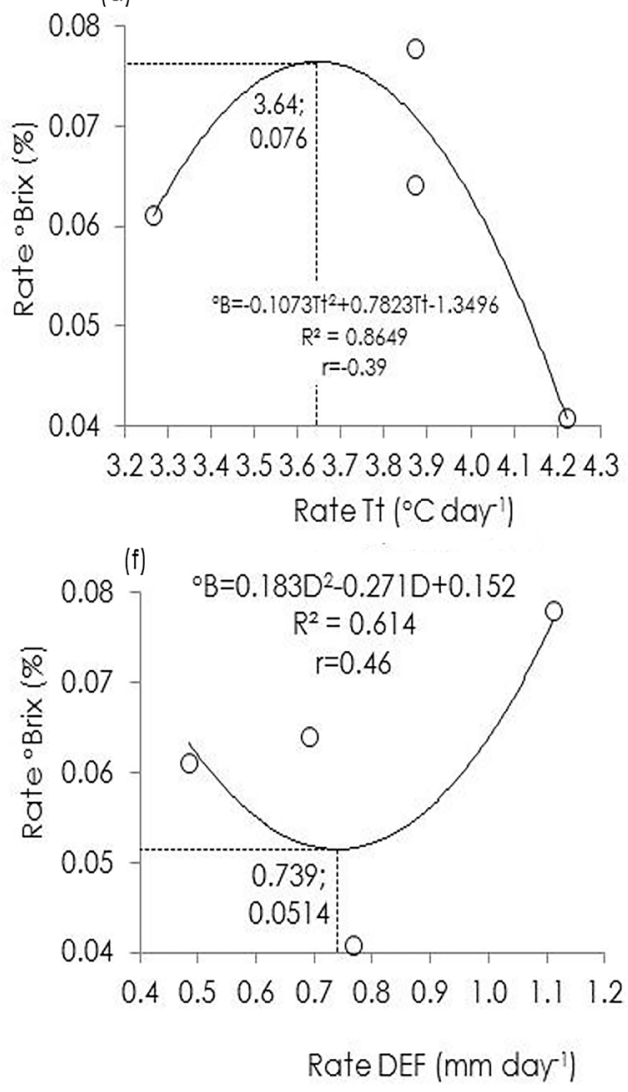

Figure 8. Rates of total recoverable sugar content (TRS, $\mathrm{kg} \mathrm{t}^{-1} \mathrm{day}^{-1}$ ) and percentage of soluble solids in juice ('Brix, \% day ${ }^{-1}$ ), in function of thermal time rates $\left(\mathrm{Tt}^{\circ}{ }^{\circ} \mathrm{C}\right.$ day ${ }^{-1}$ ) [graphics (a) and (d)], negatives degree-day rates (NDD day ${ }^{-1}$ ) [graphics (b) and (e)] and water stress rates (DEF, mm day-1) [graphics (c) and (f)].

of influence on productivity of sugarcane in negative degrees days and water stress.

Productivities showed $50 \%$ breaks in ratoon cycles in relation to the plant-cane cycle. They were attributed not only to water stress.

From the water balance analysis, it was found that deficit blades of approximately $10 \mathrm{~mm}$ for a linear behavior and $6 \mathrm{~mm}$ for an exponential behavior reflect in a $r E T=0.5$. It is worth remembering that studies evaluating the transpiration potential of sugarcane are necessary to adjust one of these models in order to detect the actual demand of plants in function of soil water blade.

The water stress showed a small influence on plants due to the moments at which it occurred, for in moments considered critical to the crop, water blades on the soil kept an $r E T>0.8$. Thermal time values were sufficient for the accumulation of sugars. However, the negative accumulated degrees days and water stress values did not reached their potential values 


\section{Acknowledgments}

We thank the Federal University of Goiás and the plant sugarcane Center Alcool ${ }^{\circledR}$, which availability its production areas, made productivity assessments and technology analysis for the sugarcane crop.

\section{References}

Almeida, A.C.S., Souza, J.L., Teodoro, I., Barbosa, G.V.S., Moura, G., Júnior, R.A.F. 2008. Desenvolvimento vegetativo e produção de variedades de cana-de-açúcar em relação à disponibilidade hídrica e unidades térmicas. Ciências Agrotecnológicas 32: 1441-1448.

Araujo, R., Alves Júnior, J., Casaroli, D., Evangelista, A.W.P. 2015. Variation in the sugar yield in response to drying-off of sugarcane before harvest and the occurrence of low air temperatures. Bragantia s/v.: 1-10.

Baquero, J.E., Ralisch, R., Medina, C.C., Tavares Filho, J., Guimarães, M.F. 2012. Soil physical properties and sugarcane root growth in a Red Oxisol. Revista Brasileira de Ciência do Solo 36: 63-70.

Campos, P.F., Alves Júnior, J., Casaroli, D., Fontoura, P.R., Evangelista, A.W.P. 2014. Variedades de cana-de-açúcar submetidas à irrigação suplementar no cerrado goiano. Engenharia Agrícola 34: $1139-1149$.

Caputo, M.M., Silva, M.A., Beauclair, E.G.F., Gava, G.J.C. 2007. Acúmulo de sacarose, produtividade e florescimento de cana-deaçúcar sob reguladores vegetais. Interciência 32: 834-840.

Casaroli, D., Jong Van Lier, Q. de, Dourado Neto, D. 2010. Validation of a root water uptake model to estimate transpiration constraints. Agricultural Water Management 97: 1382-1388.

CONAB-Companhia Nacional de Abastecimento. 2016. Acompanhamento da safra brasileira de cana-de-açúcar, Safra 2016/17 - Segundo Levantamento. Conab, Brasília, Brasil. $72 \mathrm{p}$.

Dantas Neto, J.D., Figueredo, J.L. da, Farias, C.H.A., Azevedo, H.M. de, Azevedo, C.A.V. de. 2006. Resposta da cana-de-açúcar, primeira soca, a níveis de irrigação e adubação de cobertura. Revista Brasileira de Engenharia Agrícola e Ambiental 10: 283-288.

Doorenbos, J., Kassam, A.H. 1979. Yields response to water. FAO (Irrigation and Drainage Paper, 33), Rome, Italy. $193 \mathrm{p}$.
Inman-Bamber, N.G., Smith, D.M. 2005. Water relations in sugarcane and response to water deficits. Field Crops Research 92: 185-202.

Iskandar, H.M, Casu, R.E., Fletcher, A.T., Schmidt, S., Xu, J., Maclean, D.J., Manners, J. M., Bonnett, G.D. 2011. Identification of drought-response genes and a study of their expression during sucrose accumulation and water deficit in sugarcane culms. BMC Plant Biology 11: 14712229.

Loarie, S.R, Lobell, D.B., Asner, G.P., Mu, Q., Field, C.B. 2011. Direct impacts on local climate of sugar-cane expansion in Brazil. Nature Climate Change 1: 105-109.

Machado, R.S., Ribeiro, R.V., Marchiori, P.E.R., Machado, D.F.S.P., Machado, E.C., Landell, M.G.A. 2009. Respostas biométricas e fisiológicas ao déficit hídrico em cana-de-açúcar em diferentes fases fenológicas. Pesquisa Agropecuária Brasileira 44: 1575-1582.

Marin, F.R., Carvalho, G.L. de. 2012. Spatiotemporal variability of sugarcane yield efficiency in the state of São Paulo, Brazil. Pesquisa Agropecuária Brasileira 47: 149-156.

Marin, F.R., Jones, J.W., Singels, A., Royce, F., Assad, E.D., Giampaolo, Q., Pellegrino, G.Q., Justino, F. 2013. Climate change impacts on sugarcane attainable yield in southern Brazil. Climatic Change 117: 227-239.

Metselaar, K., Jong Van Lier, Q. de. 2007. The shape of the transpiration reduction function under plant water stress. Vadose Zone Journal 6: 124-139.

Oliveira, R.A., Santos, R.S., Ribeiro, A., Zolnier, S., Barbosa, M.H.P. 2012. Estimativa de produtividade da cana-de-açúcar para as principais regiões produtoras de Minas Gerais usando-se o método ZOE. Revista Brasileira de Engenharia Agrícola e Ambiental 16: 549-557.

RIDESA-Rede Interuniversitária para o Desenvolvimento do Setor Sucroalcooleiro. 2008. Programa de melhoramento genético da canade-açúcar. Variedades RB de cana-de-açúcar. UFSCAR/CCA, Araras, Brasil. $30 \mathrm{p}$.

Scarpari, M.S., Beauclair, E.G.F. de. 2009. Physiological model to estimate the maturity of sugarcane. Scientia Agrícola 66: 622-628.

Silva, M.A., Jifon, J.L., Silva, J.A.G., Sharma, V. 2007. Use of physiological parameters as fast tools to screen for drought tolerance in sugarcane. Brazilian Journal of Plant Physiology 19: 193-201.

Trentin, R., Zolnier, S., Ribeiro, A., Steidle Neto, A.J. 2011 . Transpiração e temperatura foliar da canade-açúcar sob diferentes valores de potencial 
matricial. Engenharia Agrícola 31: 1085-1095.

Villa Nova, N.A., Pedro Junior, M.J., Pereira, A.R., Ometto, J.C. 1972. Estimativa de graus-dia acumulados acima de qualquer temperatura base, em função das temperaturas máxima e mínima. Universidade de São Paulo, Instituto de Geografia (Cardeno de Ciências da Terra, 30), São Paulo, Brasil. 8 p.

Zhao, D., Li, Y.R. 2015. Climate Change and Sugarcane Production: Potential Impact and Mitigation Strategies. International Journal of Agronomy 2015: 1-10. 